\title{
Age-related changes in T lymphocytes of patients with head and neck squamous cell carcinoma
}

\author{
S. S. Jeske ${ }^{\dagger}$, P. J. Schuler ${ }^{\dagger}$, J. Doescher, M. N. Theodoraki, S. Laban, C. Brunner, T. K. Hoffmann and M. C. Wigand ${ }^{*}$
}

\begin{abstract}
Introduction: The number of aging cancer patients has increased continuously and will do so further in the future. The immune system of elderly people experiences critical changes over the time. Therefore, tumor-induced changes in the immune system are believed to differ in young and elderly cancer patients as well.

Methods: The effect of aging on the immune system was measured in peripheral blood lymphocytes (PBL) of healthy volunteers ( $n=48,21-84$ yrs.) divided into three different age groups. Seventy years was set as a cut-off for defining subjects as elderly. Results were compared to two groups of adult cancer patients, which donated PBL and tumor infiltrating lymphocytes (TIL): young cancer patients (40-69 yrs.; blood: $n=13$; TIL: $n=17$ ) and elderly cancer patients (70-90 yrs.; blood: $n=20$; TIL: $n=15$ ) with head and neck squamous cell carcinoma (HNSCC). Frequencies and phenotypes of $\mathrm{CD}^{+}$and $\mathrm{CD} 8^{+} \mathrm{T}$ cells as well as regulatory T cells $\left(\mathrm{T}_{\text {reg }}\right)$ were assessed by flow cytometry.

Results: We observed lower frequencies of $\mathrm{CD}^{+}$cytotoxic $T$ cells during aging in both groups. Frequencies of tumor infiltrating regulatory $T$ cells were significantly higher than in the peripheral blood but showed a significant decline in older tumor patients. With increasing age, expression of immunosuppressive CD73 and CCR7 was lower and expression of PD1 elevated on peripheral T cells in healthy volunteers and tumor patients.

Conclusion: Immunosenescence takes place in healthy donors and cancer patients. Our results suggest that in elderly tumor patients, the immune system is impaired and the tumor-induced immune escape is less pronounced. The increased expression of PD1 implies the potential for effective immunotherapies in elderly, as treatment with checkpoint inhibitors could be more beneficial for elderly HNSCC patients.
\end{abstract}

Keywords: Head and neck cancer, Aging, T cells, Immunosenescence, Immune escape

\section{Introduction}

Population ageing has become one of the most significant sociological and medical issues of the twenty-first century. According to data from 'World Population Prospects' [1], the population aged 60 or above is growing faster than all younger age groups, globally. While this population group counted 962 million people in 2017, it is estimated to rise up to 2.1 billion by 2050 and up to 3.1 billion by 2100 . Besides socioeconomic issues, a growing and ageing society constitutes an immense public health burden. As it is the case for almost every malignancy, the number of older patients

\footnotetext{
* Correspondence: marlene.wigand@uniklinik-ulm.de

${ }^{\dagger}$ S. S. Jeske and P. J. Schuler contributed equally to this work.

Department of Oto-Rhino-Laryngology, Head and Neck Surgery, Ulm

University Medical Center, Frauensteige 12, 89075 Ulm, Germany
}

suffering from head and neck squamous cell carcinoma (HNSCC) has increased in the past decade and is projected to rise further in the future [2]. Despite this development, there exist only few studies concentrating on this patient subgroup. In fact, it has been under-represented in many influential studies, which have been of significant impact on standard-of-care guidelines [3]. However, carcinogenesis in older patients requires a different angle of view as the immune system undergoes a wide range of changes with increasing age. Both the innate and the adaptive immune system are affected by transformations of their constituents and functions, generally referred to as immunosenescence $[4$, 5]. The numerous alterations are contributing to not only increased susceptibility to infectious diseases and decreased response to vaccination but also to carcinogenesis in older

(c) The Author(s). 2020 Open Access This article is distributed under the terms of the Creative Commons Attribution 4.0 International License (http://creativecommons.org/licenses/by/4.0/), which permits unrestricted use, distribution, and 
people [6]. Against the background of diverse alterations in the immune system of elderly persons, our focus of interest lies in the adaptive immune system and in T lymphocytes in particular.

With increasing age, the thymus, a primary lymphoid organ, where $T$ cells mature, shrinks constantly and gets replaced by fat tissue. Consequently, the number of naïve $\mathrm{T}$ lymphocytes exiting the thymus decreases steadily. This process can be observed especially for $\mathrm{CD}^{+} \mathrm{T}$ cells [7]. As a result of the reduced output of naïve $\mathrm{T}$ lymphocytes, a relative increase of functionally exhausted memory and effector cells occurs with increasing age $[8,9]$.

After maturing in the thymus, naïve $\mathrm{T}$ lymphocytes are transported to lymph nodes, where antigen presentation as well as differentiation and proliferation of $\mathrm{T}$ lymphocytes takes place. C-C chemokine receptor type 7 (CCR7) is particularly involved in the 'homing' of T lymphocytes and dendritic cells to lymph nodes and has been reported to protect effector $\mathrm{T}$ cells from apoptosis. In HNSCC, the expression of this molecule has been found to be increased on tumor cells, which seems to be associated with the development of lymph node metastases and disease progression [10,11]. Its expression on $\mathrm{CD}^{+} \mathrm{T}$ cells, on the other hand, appears to decrease in HNSCC patients with lower $\mathrm{CD}^{+} \mathrm{CCR}^{+}$frequencies predicting disease recurrence [12]. Kim et al., postulated that CCR7 protects effector $\mathrm{T}$ cells from apoptosis and that its reduced expression on $\mathrm{CD} 8^{+} \mathrm{T}$ cells in HNSCC contributes to apoptosis and a rapid turnover of these cells [13]. Due to its relevance for disease progression, age-related changes in the expression of CCR7 could thus contribute to carcinogenesis in elderly patients.

The presence of tumor infiltrating lymphocytes (TIL) in the tumor microenvironment is known to have a relevant impact on prognosis in different types of cancer. However, it is necessary to distinguish carefully between the different subtypes of lymphocytes as they may have different and even conflicting functions [14]. Tumor-infiltrating $\mathrm{CD}^{+} \mathrm{T}$ cells, for example, act cytotoxic and have been shown to be associated with a better prognosis in different malignancies including HPV-positive and -negative HNSCC [14-16]. Tumor-infiltrating regulatory $\mathrm{T}$ cells, on the other hand, support the immunosuppressive milieu and inhibit immune response towards tumor cells. They have been observed to accumulate in aged mice and to be correlated with immune deficiency [17]. We were hence interested if we could detect age-related changes in tumor-infiltrating $\mathrm{T}$ cells in our HNSCC patient group as well.

HNSCC, in general, is regarded as an immunogenic tumor with favorable response to immunotherapeutic approaches, especially to treatment with checkpoint inhibitors [18]. One of their major targets represents the checkpoint molecule programmed cell death 1 (PD1) which promotes the immunosuppressive milieu of solid tumors. In HNSCC, PD1 has been shown to be increased both on circulating and intratumoral $\mathrm{T}$ cells with a significantly higher rate of PD1 on tumorinfiltrating $\mathrm{T}$ cells [19]. The authors proposed that this may reflect the immunosuppressive environment in HNSCC and point towards higher proportions of regulatory or exhausted T-cell phenotypes. Despite the growing number of geriatric tumor patients in clinical practice, this patient subgroup has been addressed in few clinical studies on PD1 inhibitors. To date, it seems as if age-related treatment response depends on the tumor entity. In a meta-analysis on more than 11,000 patients suffering from different tumors such as nonsmall cell lung cancer, melanoma, gastric, renal and urothelial cancer, $\mathrm{Wu}$ et al. stated that patients aged 65 and more years seem to benefit more from immunotherapy than younger patients [20]. Interestingly, in a recent study investigating the response of melanoma patients to PD1 inhibition, patients over the age of 60 responded significantly better to treatment with the anti-PD1 antibody pembrolizumab than younger patients [21]. With regards to HNSCC, age-related response rates to immunotherapy have not yet been finally clarified as only few older patients have been included into clinical trials. Against this background, we were particularly interested to examine, if differences in PD1 expression can be observed in older HNSCC patients.

Finally, it was our aim to investigate, if age has an influence on the expression of the adenosine (ADO) producing ectonucleotidases CD39 and CD73 due to our previous focus on these markers [22-24]. Adenosine has an immunosuppressive effect in the tumor micro-environment and age-related changes of CD39 and CD73 could therefore affect anti-tumor immune response in the elderly.

To sum up, the following study aimed to investigate differences in T-cell subgroups and their expression profile with increasing age both in healthy subjects and young and elderly patients who suffered from HNSCC.

\section{Material and methods Blood samples}

Peripheral blood lymphocytes (PBL) were obtained from treatment-naïve tumor patients (TB; $n=33,47-90 \mathrm{yrs)}$ and healthy volunteers $(n=48,21-84$ yrs). All participants signed an informed consent form approved by the local ethics committee (\#255/14). Blood (50 ml) was collected in S-monovettes prefilled with trisodium citrate (Sarstedt) and centrifuged on Biocoll Separating Solution (Merck) or Pancoll (density: 1119 $\mathrm{g} / \mathrm{ml}$ and $1077 \mathrm{~g} / \mathrm{ml}$; PAN Biotech). PBL were recovered, washed twice, and stored for further experiments in liquid nitrogen. Subjects were divided in five groups, predefined by their diagnosis and age (group 1: healthy subjects, 21-39 years; group 2: healthy subjects, 40-69 years; group 3: healthy subjects, 70-90 years; group 4: tumor patients, age 40-69 years; 
group 5: tumor patients age 70-90 years). Seventy years was used as cut-off for defining patients as elderly in accordance to numerous other current studies [25-27]. Clinicopathological and demographic parameters are listed in Table 1.

\section{Tumor infiltrating lymphocytes}

Tumor tissue (TT) of the same treatment-naïve patients was collected directly after surgery in $\mathrm{NaCl}$, whenever possible ( $n=32,46-90 \mathrm{yrs}$ ). Minced tissue pieces were collected in RPMI medium (Gibco) containing $200 \mathrm{IU} / \mathrm{ml}$ Collagenase I (Worthington) for at least $2 \mathrm{~h}$ at $37^{\circ} \mathrm{C}$. After digestion the tissue was mashed with a $100 \mu \mathrm{m}$ EASY strainer (Gibco). The lymphocyte fraction was isolated via Pancoll centrifugation. The purity of the cells was measured by anti-CD45 staining. Clinicopathological and demographic parameters are listed in Table 1 as well.

\section{Antibodies and reagents}

The following anti-human monoclonal antibodies (mAbs) were used for flow cytometry: CD4 Alexa Fluor ${ }^{\circ} 700$, CD8 APC, CD39 PE-Cy7, CD73 FITC, and CD73 eFluor450, CCR7 (CD197) PE-Cy7, PD1 (CD279) PE (eBioscience); CCR7 PE-CF594, CD45 AmCyan and CD45 FITC (Becton Dickinson), CD3 APC-H7, CD25 FITC (BioLegend) and CD25 PE (MACS Miltenyi). All mAbs were titrated using normal PBL to establish optimal dilution. $\mathrm{T}_{\text {reg }}$ were defined by their ability to produce extracellular adenosine as previously described by Deaglio and Borselino [28, 29]. We have previously demonstrated that these $\mathrm{CD} 4^{+} \mathrm{CD} 39^{+} \mathrm{CD} 25^{+}$ $\mathrm{T}_{\text {reg }}$ are $\mathrm{FOXP3}^{+} \mathrm{CD} 127^{\text {neg }}[24]$.

\section{Surface staining}

Cells were incubated with mAbs at RT for $30 \mathrm{~min}$ in the dark, then washed and collected in PBS for flow cytometry

Table 1 Clinicopathological parameters of the patients' blood

\begin{tabular}{|c|c|c|c|c|c|c|c|}
\hline & Group 1 & Group 2 & Group 3 & Group 4 blood & Group 5 blood & Group 4 TIL & Group 5 TIL \\
\hline Mean age (range) & $26.1(21-35)$ & $51.4(40-67)$ & $75.6(70-84)$ & $58.2(47-65)$ & 79.1 (70-90) & $57.9(46-68)$ & $79.4(70-90)$ \\
\hline \multicolumn{8}{|l|}{ Gender } \\
\hline Male & 10 & 12 & 10 & 9 & 16 & 13 & 13 \\
\hline Female & 5 & 5 & 6 & 4 & 4 & 4 & 2 \\
\hline \multicolumn{8}{|l|}{ T classification } \\
\hline T1 & & & & 0 & 6 & 0 & 5 \\
\hline $\mathrm{T} 2$ & & & & 3 & 1 & 4 & 0 \\
\hline T3 & & & & 5 & 6 & 6 & 5 \\
\hline T4 & & & & 5 & 6 & 5 & 5 \\
\hline Tx & & & & 0 & 1 & 2 & 0 \\
\hline \multicolumn{8}{|l|}{ N classification } \\
\hline NO & & & & 1 & 11 & 1 & 7 \\
\hline $\mathrm{N} 1$ & & & & 3 & 4 & 5 & 4 \\
\hline N2 & & & & 8 & 3 & 9 & 3 \\
\hline N3 & & & & 1 & 2 & 2 & 1 \\
\hline \multicolumn{8}{|l|}{ M classification } \\
\hline MO & & & & 13 & 16 & 16 & 12 \\
\hline M1 & & & & 0 & 3 & 1 & 3 \\
\hline$M x$ & & & & 0 & 1 & 0 & 0 \\
\hline Death & & & & 5 & 7 & 7 & 6 \\
\hline \multicolumn{8}{|l|}{ HPV-status } \\
\hline Positive & & & & 2 & 0 & 2 & 0 \\
\hline \multicolumn{8}{|l|}{ Localization } \\
\hline Pharynx & & & & 9 & 5 & 10 & 6 \\
\hline Larynx & & & & 2 & 6 & 2 & 4 \\
\hline Mouth & & & & 1 & 4 & 2 & 1 \\
\hline Nose & & & & 1 & 0 & 1 & 0 \\
\hline CUP & & & & 0 & 1 & 2 & 0 \\
\hline Other & & & & 0 & 4 & 0 & 4 \\
\hline
\end{tabular}


analysis. All flow cytometry measurements were performed using a Gallios 10-color-flow-cytometer equipped with Kaluza flow cytometry software (both Beckman Coulter). The acquisition and analysis gates were restricted to the lymphocyte gate based on characteristic properties of the cells in forward and side scatter. At least $10^{5}$ cells were acquired for the analysis.

\section{T-cell culture}

PBL were cultured in 96-well plates $\left(2 \times 10^{5}\right.$ cells/well $)$ containing RPMI $+10 \%$ FBS superior (Merck, USA), 100 $\mathrm{U} / \mathrm{ml}$ penicillin and $100 \mu \mathrm{g} / \mathrm{ml}$ streptomycin (Pan Biotech, Germany). Cells were stimulated with anti-CD3 $(1 \mu \mathrm{g} / \mathrm{ml}$, BD) and three concentrations of anti-CD28 $(1 \mu \mathrm{g} / \mathrm{ml}$, $5 \mu \mathrm{g} / \mathrm{ml}$ or $10 \mu \mathrm{g} / \mathrm{ml}$; BD) and cultured for at least 7 days $\left(37^{\circ} \mathrm{C}, 5 \% \mathrm{CO}_{2}\right)$. FACS analysis of $\mathrm{CD} 73$ on the T-cell subpopulations was performed as described above.

\section{Statistical analysis}

All data are presented as means of at least three experiments. Data were tested for Gaussian distribution using Shapiro-Wilk test. One-Way ANOVA or Kruskal-Wallis test were used to test for group differences as appropriate. Mann-Whitney test was applied for non-parametric parameters. For correlation analyses, Pearson and Spearman test were used for parametric and non-parametric values, respectively. The significance value for $p$-values was set at $\leq 0.05$. All statistical analyses were performed using GraphPad Prism Version 6.01.

\section{Results}

\section{Age-related changes in lymphocyte subsets}

In healthy donors, a negative correlation between age and the frequency of $\mathrm{CD} 8^{+}$cytotoxic $\mathrm{T}\left(\mathrm{T}_{\mathrm{c}}\right)$ cells was observed $\left(p<0.001\right.$, Fig. 1a) while the frequency of $\mathrm{CD} 4^{+} \mathrm{T}$ helper $\left(\mathrm{T}_{\mathrm{h}}\right)$ cells remained relatively stable $(p<0.1$, Fig. $1 \mathrm{~b})$. Probably due to the limited number of samples, this effect could not be reproduced, when the predefined age groups were compared (Fig. 1c and d). We saw a significant positive correlation between age and the $\mathrm{CD} 4 / \mathrm{CD} 8$ ratio in healthy subjects $(p<0.001$, Additional file 1: Figure S1A). The frequency of regulatory $T$ cells $\left(\mathrm{T}_{\text {reg }}\right)$ in the blood remained stable for all age groups (Fig. 1e). In healthy donors, we observed a negative correlation between peripheral CD4 ${ }^{+} \mathrm{T}_{\mathrm{h}}$ cells and $\mathrm{T}_{\text {reg }}\left(p<0.01, R^{2}=0.2\right.$; Additional file 1: Figure $\mathrm{S1B})$, indicating that the unchanged proportion of $\mathrm{T}_{\text {reg }}$ is not affected by a lower $\mathrm{CD} 4^{+} \mathrm{T}_{\mathrm{h}}$ cell frequency.

In tumor patients' blood (TB), the frequency of $\mathrm{CD}^{+}$ $\mathrm{T}$ cells showed a slight decrease in elderly patients similar to our observations in healthy volunteers $(p=0.08$, Fig. 1c). The frequency of $\mathrm{CD} 4^{+} \mathrm{T}$ cells and $\mathrm{T}_{\text {reg }}$ remained stable for young and elderly cancer patients (Fig. 1d and e). In tumor tissue (TT) samples, the frequency of $\mathrm{CD}^{+}$TIL was comparable to PBL of cancer patients with no significant age-related changes (Fig. 1c). However, the frequency of infiltrating $\mathrm{CD} 4^{+} \mathrm{T}$ cells was significantly lower $(p<0.0001)$ than in $\mathrm{PBL}$, and remained stable with increasing age (Fig. 1d). Interestingly, $\mathrm{T}_{\text {reg }}$ showed significantly higher frequencies in tumor tissue as compared to blood samples (Fig. 1e). However, the frequency of tumor-infiltrating $\mathrm{T}_{\text {reg }}$ decreased in elderly cancer patients as compared to young tumor patients and showed an inverse correlation to age $\left(p<0.01, R^{2}=0.2\right.$; Fig. 1e and f). Despite this decline, the frequency of tumor-infiltrating $\mathrm{T}_{\text {reg }}$ in elderly tumor patients was still significantly higher than in the peripheral blood. As there were many possible confounders for altered frequencies of TIL subsets, we tested for differences in tumor site, T stage, HPV status and gender by setting these parameters as confounders in separate ANOVA tests. The tests showed that the observed results were not confounded by any of the stated factors (data not shown). Additionally, the total numbers of lymphocytes were analyzed in all blood samples. We observed an age-dependent decrease of $\mathrm{CD}^{+} \mathrm{T}_{c}$ cells in the peripheral blood of healthy volunteers $(p<0.001$, $R^{2}=0.1$ ), which was not seen in cancer patients (Additional file 1: Figure S1C). The decrease of $\mathrm{CD}^{+} \mathrm{T}_{\mathrm{c}}$ cells was also seen for the age group $\geq 70$ years in age group comparisons $(p<0.05$, Additional file 1: Figure S1D). No such age-dependent correlations were detected for $\mathrm{CD} 4^{+}$ $\mathrm{T}_{\mathrm{h}}$ cells or $\mathrm{T}_{\text {reg }}$ (Additional file 1: Figure S1E and F). Incidentally, no group differences were detected, when cell counts of total lymphocytes were analyzed.

\section{Expression of the ectonucleotidases CD39 and CD73}

To further characterize the $\mathrm{T}$ cell subpopulations, we analyzed the expression of the adenosine (ADO) producing ectonucleotidases CD39 and CD73, which can define a variety of regulatory cell populations $[22,23,30] . \mathrm{CD}^{+} \mathrm{T}_{\mathrm{h}}$ cells of the blood can be divided into three subpopulations based on their expression of CD39 and CD73: (I) CD39 ${ }^{+} \mathrm{T}_{\text {reg }}$ (II) activated $\mathrm{CD}^{+} 3^{+} \mathrm{T}_{h}$ cells, and (III) double negative $\mathrm{T}_{h}$ cells (Fig. 2a). As described before, the co-expression of CD39 and CD73 is extremely rare in peripheral CD4 $4^{+} \mathrm{T}_{\mathrm{h}}$ cells [24]. In contrast, the frequency of $\mathrm{CD} 44^{+} \mathrm{CD} 39^{+} \mathrm{T}_{\text {reg }}(p<0.05$; Fig. 2B) and of double-positive $\mathrm{CD} 4^{+} \mathrm{CD} 39^{+} \mathrm{CD} 73^{+} \mathrm{T}$ cells $(p<$ 0.0001; Fig. 2C) was increased in the tumor tissue as compared to peripheral blood.

Interestingly, the expression of CD73 was significantly lower $(p<0.0001)$ on peripheral $\mathrm{CD}^{+} \mathrm{T}$ cells of older healthy volunteers, while CD39 was nearly not expressed on peripheral $\mathrm{CD}^{+} \mathrm{T}$ cells (Fig. 3a-e). The agedependent decline of CD73 seems to persist in cancer patients, although this observation did narrowly miss statistical significance $(p=0.05)$. We assumed that the enzyme CD73 is not only responsible for the production of ADO, but also a marker for cell activity. Accordingly, 
A

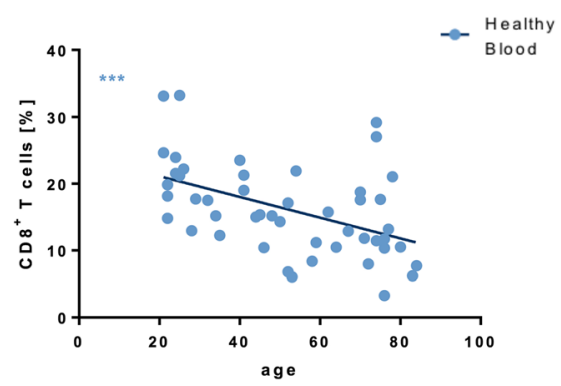

$\mathrm{C}$

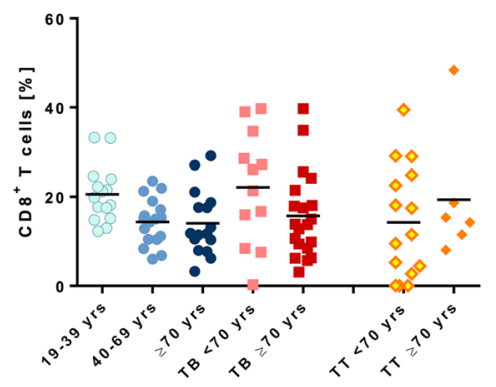

$E$

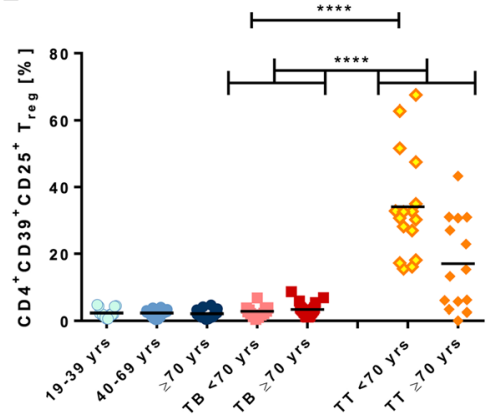

B

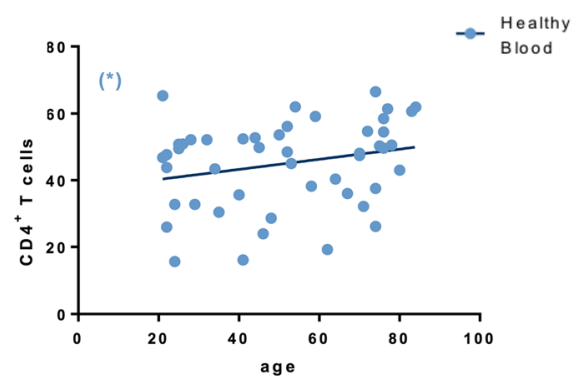

D

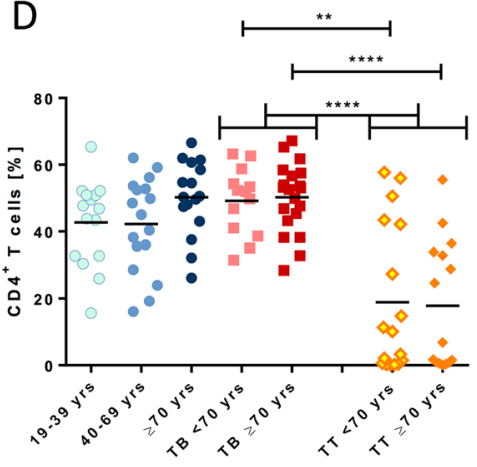

$\mathrm{F}$

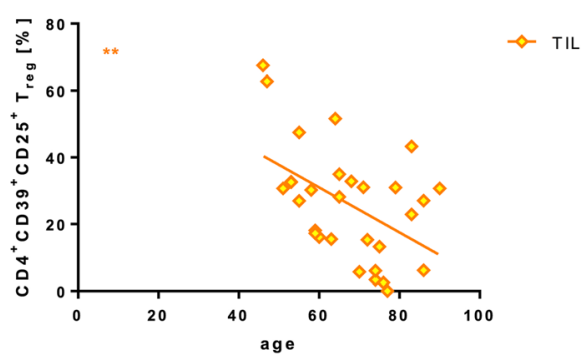

Fig. 1 Lymphocyte populations of different ages from healthy donors and HNSCC patients. Correlations between frequencies of $\mathrm{CD}^{+}$(a) and $\mathrm{CD}^{+} \mathrm{T}$ cells $(\mathbf{b})$ and age in healthy donors. Frequencies of $\mathrm{CD}^{+}(\mathbf{c}), \mathrm{CD}^{+} \mathrm{T}$ cells $(\mathbf{d})$ and $\mathrm{T}_{\mathrm{reg}}(\mathbf{e})$ in healthy donors and tumor patients of different age groups (healthy < 40: light blue; healthy $>40$ and $\leq 70$ : blue; healthy $\geq 70$ : dark blue; tumor blood (TB) < 70: light red; tumor blood 270: red; TIL (TT) < 70: yellow; TIL $\geq 70$ : orange). Cell populations were plotted in a regression line (a-b, $\mathbf{f}$ ) (healthy: blue circles; TIL: yellow rhombs). All data are plotted showing the mean. $P<0.01\left(^{* *}\right) ; p<0.001\left(^{(* *}\right) ; p<0.0001\left(^{(* *}\right)$

our data show that the expression of CD73 increases after stimulation of T-cell subpopulations in a timedependent manner $(p<0.01$, Fig. 2 d). We also tested different concentrations of CD28 from 1 to $10 \mu \mathrm{g} / \mathrm{ml}$, but saw no differences (data not shown). After prolonged stimulation, the initial expression of CD73 diminished on days 3 to 7 , possibly due to cell fatigue (data not shown). We were surprised to see that the expression of the ectonucleotidases CD39 and CD73 was reversed on tumor-infiltrating $\mathrm{CD}^{+} \mathrm{T}_{\mathrm{c}}$ cells, which are mostly $\mathrm{CD}_{3} 9^{+} \mathrm{CD} 3^{\text {neg }}$ in comparison to peripheral $\mathrm{CD}^{+} \mathrm{T}_{\mathrm{c}}$ cells, which are mainly $\mathrm{CD} 39^{\text {neg }} \mathrm{CD} 73^{+}$(Fig. $3 \mathrm{a}$ and b).

\section{Age-related increase of PD1}

All $\mathrm{T}$ cell subpopulations showed low levels of PD1 expression on their surface $(\sim 10 \%)$, while all TIL populations expressed significantly higher PD1 levels than tumor blood cells (Fig. 4a-c). In healthy volunteers, PD1 expression showed a positive correlation with age on all $\mathrm{T}$ cell subpopulations $\left(\mathrm{CD}^{+} \mathrm{T}_{\mathrm{c}}\right.$ cells: $p<0.01, R^{2}=0.08$; $\mathrm{CD}^{+} \mathrm{T}_{\mathrm{h}}$ cells: $p<0.05, R^{2}=0.09$; $\mathrm{T}_{\mathrm{reg}}: p<0.05, R^{2}=$ 0.09; Fig. $4 \mathrm{~d}-\mathrm{f}$ ). The same correlation was observed in the blood of tumor patients $\left(\mathrm{CD}^{+} \mathrm{T}_{\mathrm{c}}\right.$ cells: $p<0.05$, $R^{2}=0.03 ; \mathrm{CD}^{+} \mathrm{T}_{\mathrm{h}}$ cells: $p<0.1, R^{2}=0.04 ; \mathrm{T}_{\text {reg }}: p<0.05$, $R^{2}=0.07$; Fig. $4 \mathrm{~d}-\mathrm{f}$ ). 

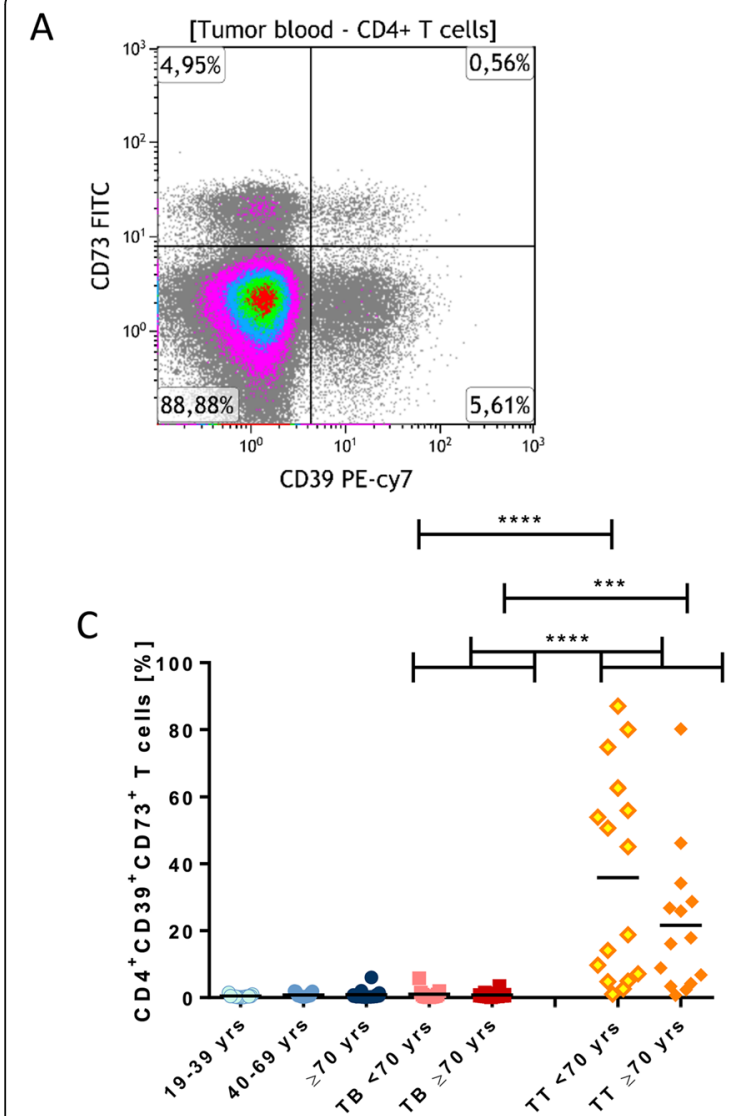

B

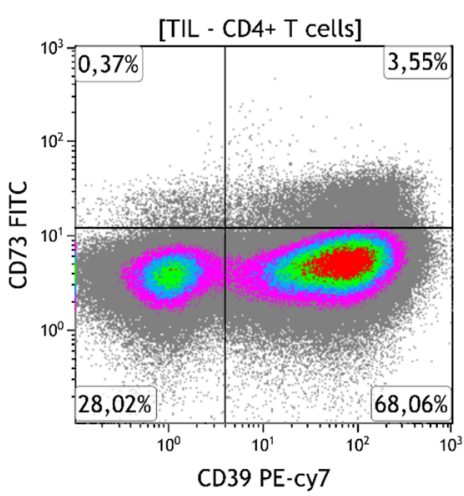

D

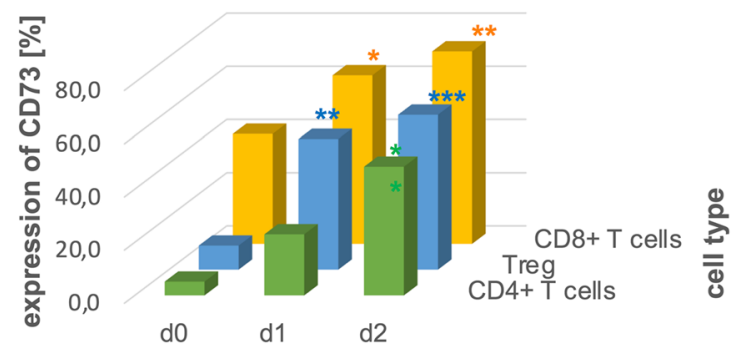

days of stimulation

Fig. 2 Expression levels of the ectonucleotidases CD39 and CD73 on CD4 ${ }^{+} \mathrm{T}$ cells in healthy donors and HNSCC patients in comparison as well as CD73 expression in response to T-cell stimulation. PBL were examined for surface expression of the ectonucleotidases CD39 and CD73 by FACS (a-b). The CD39 and CD73 characterization of CD4 ${ }^{+} T$ cells of the healthy and tumor blood in representative density plots. The coexpression of CD39 and CD73 on CD4 $4^{+}$blood T cells were plotted for healthy donors and tumor patients and compared to CD4 ${ }^{+}$TIL (c). PBL were incubated with anti-CD3 and anti-CD28 for at least 2 days. The frequency of CD73 on CD8 ${ }^{+}, T_{\text {reg }}$ and $C D 4^{+} T$ cells was measured by FACS before and after each day of stimulation $(n=4)(\mathbf{d})$. Data were analyzed with a Two-Way ANOVA and shown as mean; $p<0.05(*) ; p<0.01\left(^{* *}\right)$; $\left.p<0.0011^{(* *}\right)$

\section{Age-related decrease of CCR7}

The expression of CCR7 on $\mathrm{CD}^{+} \mathrm{T}_{\mathrm{c}}$ cells dropped significantly with age in healthy volunteers $(p<0.0001$; Fig. $5 \mathrm{a}$ and b). Interestingly, expression of CCR7 was even lower on $\mathrm{CD}^{+} \mathrm{T}_{\mathrm{c}}$ cells of cancer patients (Fig. 5a). However, this observation may be partly biased by the increased mean age in the cancer patient cohort. A further decrease of CCR7 expression was observed in tumor-infiltrating $\mathrm{CD}^{+} \mathrm{T}_{\mathrm{c}}$ cells when compared to peripheral blood of tumor patients $(p=$ 0.06; Fig. 5a). Exemplary density plots for CCR7 expression on $\mathrm{CD}^{+} \mathrm{T}_{\mathrm{c}}$ cells are shown in Fig. 5c-f. CCR7 expression on $\mathrm{CD}^{+} \mathrm{T}$ cells of healthy subjects and tumor patients remained stable over age, but its expression was significantly lower in tumor patients $(p<0.01)$ as compared to healthy volunteers and in TIL compared to PBL of tumor patients $(p<0.05)$ (Additional file 2: Figure S2A and B). In $\mathrm{T}_{\text {reg, no }}$ differences were seen for CCR7 expression with data not being available for all tumor samples (Additional file 2: Figure S2C and D). The co-expression of PD1 and CCR7 on all observed T cell populations was higher on TIL when compared to peripheral blood $\mathrm{T}$ cells (data not shown). The low levels of CCR7 on $\mathrm{CD}^{+}$and $\mathrm{CD} 8^{+} \mathrm{T}$ cells in the tumor tissue compared to the blood of tumor patients are shown in representative density plots (Additional file 2: Figure S2E).

\section{Discussion}

Our data reveal numerous age-dependent alterations of Tcell populations both in healthy controls and in cancer patients. Especially on $\mathrm{CD}^{+} \mathrm{T}_{\mathrm{c}}$ cells, we found a number of changes due to aging, which demonstrate immunosenescence in elderly healthy volunteers, including (I) decreased frequency and absolute number in the peripheral blood, (II) decreased cell activity measured by CD73 expression, (III) increased expression of the checkpoint PD1, and (IV) decreased CCR7 expression. We hypothesize that the mechanisms of tumor-induced immune suppression may be less pronounced in elderly patients with the remaining ones being targetable (PD1). The decreased tumor- 

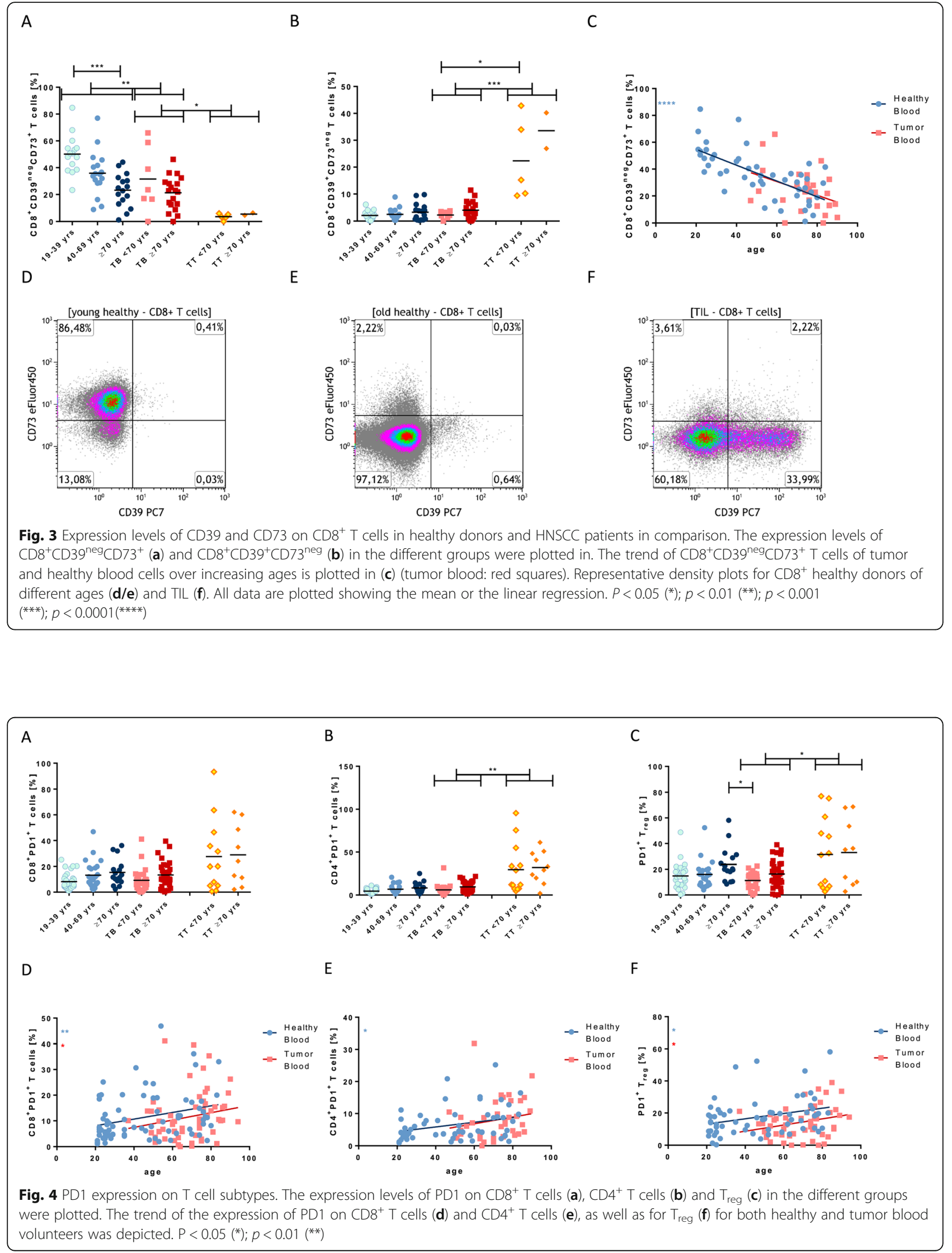


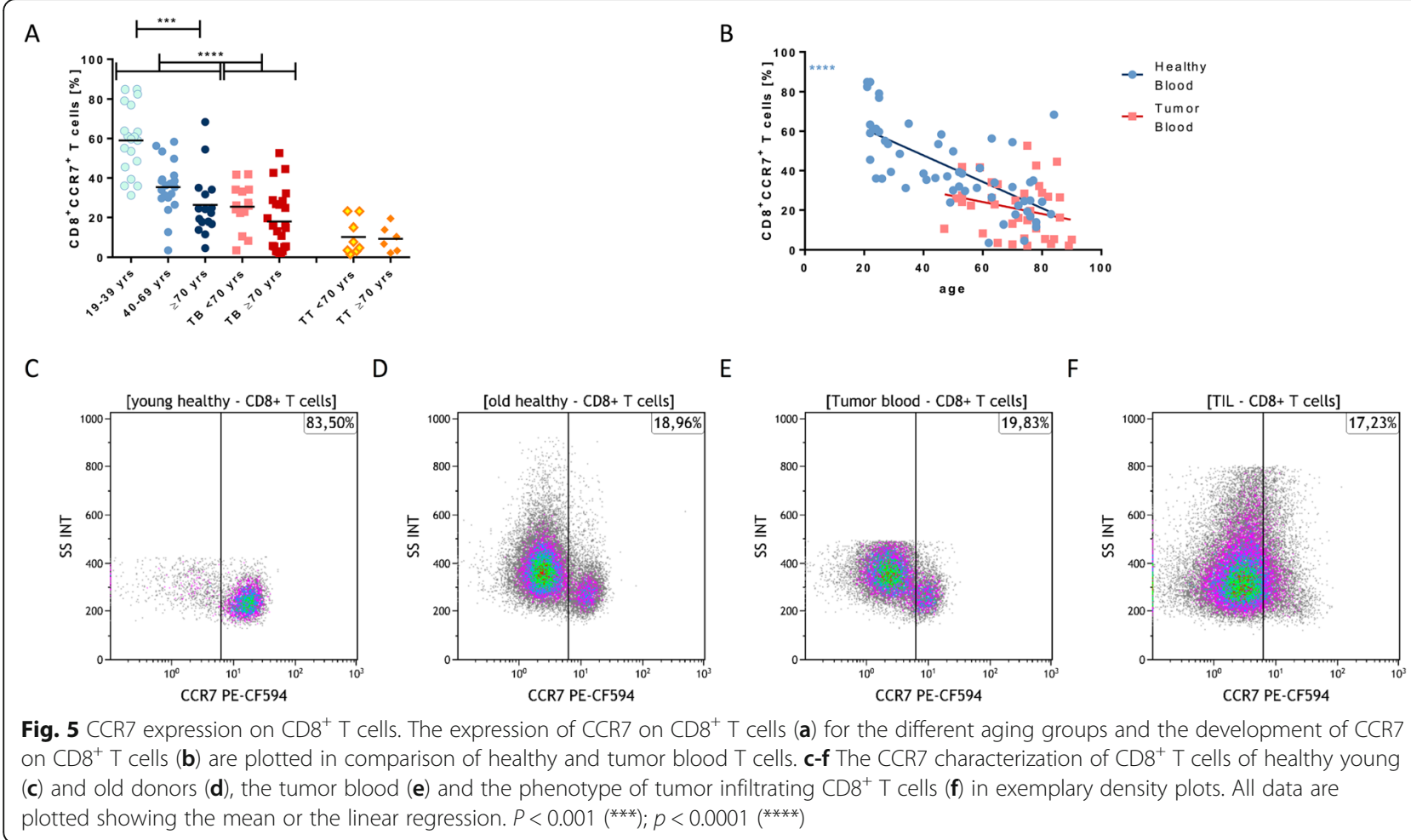

induced immune suppression is indicated by a decreased frequency of tumor-infiltrating $\mathrm{T}_{\text {reg }}$ and a decreased production of extracellular ADO by $\mathrm{CD}^{+} 3^{+}$immune cells (Additional file 3: Figure S3).

\section{Frequency and number of $\mathrm{T}_{\mathrm{c}}$ cells}

Both healthy subjects and tumor patients showed an agerelated decrease in $\mathrm{CD}^{+} \mathrm{T}_{\mathrm{c}}$ cells regarding frequency and total numbers in our cohort (Fig. 1a and c, Additional file 1: Figure S1C and D). As the size of the thymus - the place where $\mathrm{T}$ lymphocytes mature - decreases significantly with age, the number of naïve $\mathrm{T}$ lymphocytes exiting the thymus is reduced in older subjects [7]. Accordingly, the frequency of naïve $T$ cells decreases, while the frequency of memory and effector cells increases with age. As described by Saavedra et al., the number and proportion of naïve $\mathrm{CD}^{+}$lymphocytes may be reduced due to a decreased output of naïve lymphocytes with increasing age while terminally differentiated $\mathrm{CD}^{+} \mathrm{T}$ cells accumulate [31]. The frequency of tumorinfiltrating $\mathrm{CD}^{+} \mathrm{T}_{\mathrm{c}}$ cells, on the other hand, remained stable in our cohort of elderly cancer patients. In general, higher counts of intratumoral $\mathrm{CD}^{+} \mathrm{T}_{\mathrm{c}}$ cells have been related to a better prognosis in different types of cancer including HNSCC [14-16]. In addition, we observed a positive correlation between the $\mathrm{CD} 4^{+} / \mathrm{CD}^{+} \mathrm{T}$-cell ratio and age in our healthy subjects (Additional file 1: Figure S1A), which is supported by the data of others [32]. This age-related increase of the $\mathrm{CD}^{+} / \mathrm{CD}^{+} \mathrm{T}$-cell ratio was not seen in our group of cancer patients. Remarkably, in lung cancer patients, an increased $\mathrm{CD} 4^{+} / \mathrm{CD} 8^{+} \mathrm{T}$-cell ratio has been associated with a better response to an experimental EGF cancer vaccine [33]. In nasopharyngeal carcinoma, patients with higher $\mathrm{CD}^{+} /$ $\mathrm{CD}^{+}$T-cell ratios showed a better survival than patients with lower ratios [34]. This positive effect of an elevated $\mathrm{CD}^{+} / \mathrm{CD}^{+}$T-cell ratio seems to be compromised in those patients suffering from cancer in our cohort which might point towards a more disadvantageous composition of the immune system in the latter. It seems as if disturbances in the physiological age-related changes in the $\mathrm{T}$ cell system are at least partially associated with carcinogenesis.

\section{Expression of ectonucleotidases CD39 and CD73}

Our data show that the enzyme CD73 not only is responsible for the production of ADO [23], but also acts as an activity marker, as it increases after stimulation on all $\mathrm{T}$-cell subpopulations, in vitro (Fig. 2d). Interestingly, the expression of $\mathrm{CD} 73$ on $\mathrm{CD}^{+} \mathrm{T}_{\mathrm{c}}$ cells showed a negative correlation with age in healthy individuals and in our small cohort of tumor patients (Fig. 3c). This may be indicative for a decreased activity of $\mathrm{CD} 8^{+}$ $\mathrm{T}_{\mathrm{c}}$ cells in elderly subjects. As the immune cells become less active with increasing age, there may be a decreased need for the production of immunosuppressive ADO in the blood and tissue of elderly individuals, which is partly regulated by the expression CD73. Although, this hypothesis is intriguing, we cannot support it by experimental data so far. 


\section{Expression of checkpoint PD1}

The checkpoint PD1 is an immune checkpoint molecule, which is expressed on a variety of immune cells. Activation of PD1 induces a decreased activity of these cells [35]. High expression of PD1 may, therefore, be linked to a decreased activation status of the immune system.

Interestingly, PD1 expression increased with age on all T cell subpopulations both in healthy volunteers and in tumor patients indicating a shift towards increased immunosuppression in older subjects (Fig. 4). It is therefore reasonable, that elderly cancer patients show a better response to clinical PD1-inhibition than younger patients, as shown by Kugel et al. in a cohort of melanoma patients [21]. Regarding HNSCC, current studies on the treatment response of older tumor patients after immunotherapy are still rare. The Keynote- 012 trial on the efficacy and safety of pembrolizumab in recurrent or metastatic HNSCC revealed an overall response rate of $18 \%$ with the average age of patients being 63 years [36]. No data on possible correlations between age and treatment response were found in this study. The Checkmate-141 trial compared the efficacy of nivolumab with standard, single-agent systemic therapy on HNSCC patients with progressive recurrent disease within 6 months after platinum-based chemotherapy [37]. Initially, patients between 65 and 75 years showed no differences between the two treatment arms, while the overall survival of younger patients was significantly longer with nivolumab. A second data analysis 2 years later, however, showed a significant survival benefit with nivolumab regardless of demographic characteristics which indicates a compensation of the initial impact of age [38]. Consequently, in their analysis of the Checkmate-141 study Saba et al. recommended the use of nivolumab in relapsing or metastatic HNSCC patients regardless of age [39]. The increased PD1 expression on tumor-infiltrating lymphocytes as compared to peripheral lymphocytes is certainly affecting treatment response as well, although there was no correlation with age for this observation.

\section{Expression of chemokine receptor CCR7}

The chemokine receptor CCR7 is responsible for the homing of $\mathrm{T}$ cells as well as dendritic cells to lymph nodes and contributes to tolerance induction [40]. Furthermore, CCR7 can activate both B and T lymphocytes and stimulate dendritic cell maturation, and it is known as a classical central memory marker [41].

The increased expression of CCR7 on tumor cells has been shown to be associated with a poor prognosis and with the development of lymph node metastases in HNSCC $[11,42]$. While the expression of CCR7 on HNSCC cells is increased, both in cell lines and patients [10], the frequency of peripheral $\mathrm{CD} 8^{+} \mathrm{CCR} 7^{+} \mathrm{T}_{\mathrm{c}}$ cells has been found to be decreased in HNSCC patients [12, 13], which in turn is associated with disease recurrence. Generally, CCR7 on peripheral $\mathrm{CD}^{+} \mathrm{T}_{\mathrm{c}}$ cells is linked to a good outcome for HNSCC patients [12]. We were able to confirm the previous findings of decreased CCR7 expression on $\mathrm{CD}^{+} \mathrm{T}_{\mathrm{c}}$ cells in tumor patients. Moreover, we detected that the generally higher frequency of protecting $\mathrm{CCR}^{+}$cells in healthy subjects decreased with age, yet still being higher than in tumor patients (Fig. 5). The observed age-related decrease of CCR7 $7^{+} T_{c}$ cells may be another result of immunosenescence contributing to the weaker and less responsive immune system in the elderly.

We are well aware that our flow cytometry data should ideally be complemented by additional flow data for FOXP3 and immunohistochemistry. However, in our hands all tumor tissue was urgently needed for the acquisition of fresh TIL. Based on our previously published date, we, therefore, postulate that $\mathrm{CD} 4^{+} \mathrm{CD} 39^{+} \mathrm{CD} 25^{+}$ are all $\mathrm{FOXP3}^{+}$.

It has been described repeatedly that frequencies of $\mathrm{T}_{\text {reg }}$ are elevated in the tumor environment reflecting an immunosuppressive micromilieu $[19,43]$. As a result of the fragile immune system in elderly, tumor-induced immune suppression may be less pronounced in aged patients. This hypothesis is supported by the observation that the generally increased frequency of $\mathrm{T}_{\text {reg }}$ in the tumor microenvironment is significantly decreased in elderly as compared to younger cancer patients (Fig. 1e and $f$ ). $T_{\text {reg }}$ are supposed to suppress the immune response to tumor-associated antigens. Ambivalently, their presence appears to have diverse prognostic effects depending on the type of cancer. In pancreatic ductal adenocarcinoma, for example, an increased prevalence of $\mathrm{T}_{\text {reg }}$ has been associated with a poorer prognosis and reduced patient survival [44]. As for HNSCC, however, their presence has been associated with improved survival, particularly in tumors of oropharyngeal origin [16, 45]. The decrease of $\mathrm{T}_{\text {reg }}$ in tumor tissue of elderly patients could, therefore, indicate a less responsive immune system in this age group which could contribute to a worse outcome of older HNSCC patients. The phenomenon of lower $T_{\text {reg }}$ frequencies in tumor tissue of older patients has been stated in a recent melanoma study comparing $\mathrm{T}_{\text {reg }}$ in the tumor of young and aged mice. Intriguingly, this finding has been confirmed by observations in humans, in which lower $\mathrm{T}_{\text {reg }}$ frequencies in the tumor tissue were associated with a better response to the PD1 inhibitor pembrolizumab [21]. As elderly patients often do not benefit from chemoradiotherapy [46], treatment with checkpoint inhibitors could possibly present a better alternative or adjuvant therapy option for this patient subgroup.

\section{Conclusion}

Our data demonstrate numerous age-related changes in the immune system in healthy subjects as well as in HNSCC patients. We were able to show a shift towards 
disturbed immune competence with increasing age mirrored by lower $\mathrm{CD} 8^{+} \mathrm{T}$ cell counts, decreased CCR7 and higher PD1 expression. The weaker immune system of elderly tumor patients could dispense with the need for tumor induced immunosuppression which may in turn be reflected by the lower frequency of tumor infiltrating $\mathrm{T}_{\text {reg. }}$. The number of elderly cancer patients will continuously grow in the future. A detailed knowledge of agerelated alterations of the immune system is, therefore, necessary in order to offer an adequate treatment option for this age group.

\section{Supplementary information}

Supplementary information accompanies this paper at https://doi.org/10. 1186/s12979-020-0174-7.

Additional file 1: Figure S1. (A) The CD4/CD8 ratio of the subjects were plotted against the age (Spearman Correlation). Each point represents the data of one patient linked the frequency of $\mathrm{CD}^{+} \mathrm{T}$ cells and $T_{\text {reg, }}$ which was shown plotted in (B) for the blood samples of healthy subjects (Pearson Correlation). The total cell numbers of $\mathrm{CD}^{+} \mathrm{T}$ cells of the healthy and tumor subjects were plotted against the age (Spearman Correlation) (C). The total lymphocytic numbers of the patients were divided in the five aging groups and plotted. Out of these total lymphocytic numbers the total numbers of $C D 8^{+} T$ cells (D), $C D 4^{+} T$ cells (E) and the $\mathrm{CD}_{3} 9^{+} \mathrm{CD} 25^{+} \mathrm{T}_{\text {reg }}(\mathrm{F})$ were plotted. $P<0.05\left(^{*}\right) ; p<0.01$ $\left.\left({ }^{* *}\right) ; p<0.001{ }^{* * *}\right)$. (JPG $\left.5043 \mathrm{~kb}\right)$

Additional file 2: Figure S2. PD1 and CCR7 expression on T cell subtypes. The expression of CCR7 on $C D 4^{+} T$ cells (A) for the different aging groups and corresponding plotted in comparison of healthy and tumor blood $\mathrm{CD}^{+} \mathrm{T}$ cells (B), and $\mathrm{T}_{\text {reg }}$ for the different aging groups (C) and the comparison of healthy and tumor blood $T$ cells (D). The expression of PD1 and CCR7 on CD4 ${ }^{+} T$ cells, CD8 ${ }^{+} \mathrm{T}$ cells, and $\mathrm{T}_{\text {reg }}$ of tumor patients' blood samples and the co-expression on $\mathrm{CD}^{+} \mathrm{T}$ cells, $\mathrm{CD}^{+} \mathrm{T}$ cells, and $\mathrm{T}_{\text {reg }}$ on corresponding $\mathrm{TIL}$ in representative density plots (E). All data are plotted showing the mean or the linear regression.

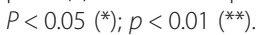

Additional file 3: Figure S3. This summary shows the connections between the young and the old subjects in this study. On the left side are mentioned the young volunteers on the right side the old. The young subjects have more $C D 8^{+} \mathrm{T}_{\mathrm{C}}$ cells expressing mainly CCR7 and CD73, while the old subjects have less, expressing more PD1. The young tumor patients have an active immune-system with a strong tumorinduced immune suppression with many $T_{\text {reg, }}$ while old patients have a senile immune system with a weak immune suppression and less $T_{\text {reg }}$

\section{Abbreviations}

ADO: Adenosine; CCR7: C-C chemokine receptor type 7; HNSCC: Head and neck squamous cell carcinoma; mAbs: Monoclonal antibodies; PBL: Peripheral blood lymphocytes; PD1: Programmed cell death 1; TB: Tumor patients' blood; $T_{c}$ : Cytotoxic T cells; $T_{h}: T$ helper cells; TIL: Tumor infiltrating lymphocytes; $T_{\text {reg: }}$ Regulatory $T$ cells; $T$ : Tumor tissue

\section{Acknowledgements}

We thank Katja Hasch, Gabriela Cudek and Monika Jerg for their support in performing the experiments.

\section{Authors' contributions}

PJS devised the project and the main conceptual ideas. MCW collected blood samples and SSJ performed the experiments and statistical analysis. MCW and SSJ interpreted the data and drafted the manuscript under supervision of PJS. JD, MNT, SL, CB and TKH aided in interpreting the results and worked individually on the manuscript. All authors read and approved the final manuscript.

\section{Funding}

The research was supported by the German Research Foundation DFG Grant \# SCHU 2536/3 (PJS) and by the International Graduate School in Molecular Medicine UIm (SSJ).

\section{Availability of data and materials}

The datasets generated and analyzed during the current study are not publicly available due to confidentiality reasons but are available from the corresponding author on reasonable request.

\section{Ethics approval and consent to participate}

This study was approved by the local ethics committee of the University Medical Center in UIm. Written informed consent was obtained from all participants.

\section{Consent for publication}

All participants gave written informed consent for publication.

\section{Competing interests}

The authors declare that they have no competing interests

Received: 2 September 2019 Accepted: 27 January 2020

Published online: 12 February 2020

\section{References}

1. Nations U. World Population Prospects. The 2017 Revision, Key Findings and Advance Tables. In: Department of Economics and Social Affairs PD, editor. New York: United Nations; 2017.

2. Smith BD, Smith GL, Hurria A, Hortobagyi GN, Buchholz TA. Future of cancer incidence in the United States: burdens upon an aging, changing nation. J Clin Oncol. 2009;27(17):2758-65.

3. Maggiore R, Zumsteg ZS, BrintzenhofeSzoc K, Trevino KM, Gajra A, KorcGrodzicki B, et al. The older adult with Locoregionally advanced head and neck squamous cell carcinoma: knowledge gaps and future direction in assessment and treatment. Int J Radiat Oncol Biol Phys. 2017;98(4):868-83.

4. Alexandraki K, Piperi C, Kalofoutis C, Singh J, Alaveras A, Kalofoutis A. Inflammatory process in type 2 diabetes: the role of cytokines. Ann N Y Acad Sci. 2006;1084:89-117.

5. Ciabattini A, Nardini C, Santoro F, Garagnani P, Franceschi C, Medaglini D. Vaccination in the elderly: the challenge of immune changes with aging. Semin Immunol. 2018;40:83-94.

6. Bottazzi B, Riboli E, Mantovani A. Aging, inflammation and cancer. Semin Immunol. 2018;40:74-82

7. Fagnoni FF, Vescovini R, Passeri G, Bologna G, Pedrazzoni M, Lavagetto $G$, et al. Shortage of circulating naive CD8(+) T cells provides new insights on immunodeficiency in aging. Blood. 2000;95(9):2860-8.

8. Haynes L, Eaton SM, Burns EM, Randall TD, Swain SL. CD4 T cell memory derived from young naive cells functions well into old age, but memory generated from aged naive cells functions poorly. Proc Natl Acad Sci U S A. 2003;100(25):15053-8.

9. Pfister G, Weiskopf D, Lazuardi L, Kovaiou RD, Cioca DP, Keller M, et al. Naive T cells in the elderly: are they still there? Ann N Y Acad Sci. 2006;1067:152-7.

10. Ueda M, Shimada T, Goto Y, Tei K, Nakai S, Hisa Y, et al. Expression of CCchemokine receptor 7 (CCR7) and CXC-chemokine receptor 4 (CXCR4) in head and neck squamous cell carcinoma. Auris Nasus Larynx. 2010;37(4):488-95.

11. Wang J, Seethala RR, Zhang Q, Gooding W, van Waes C, Hasegawa H, et al. Autocrine and paracrine chemokine receptor 7 activation in head and neck cancer: implications for therapy. J Natl Cancer Inst. 2008;100:502-12.

12. Czystowska M, Gooding W, Szczepanski MJ, Lopez-Abaitero A, Ferris RL, Johnson JT, et al. The immune signature of CD8(+)CCR7(+) T cells in the peripheral circulation associates with disease recurrence in patients with HNSCC. Clin Cancer Res. 2013;19(4):889-99.

13. Kim JW, Ferris RL, Whiteside TL. Chemokine $C$ receptor 7 expression and protection of circulating CD8+ T lymphocytes from apoptosis. Clin Cancer Res. 2005;11:7901-10.

14. de Ruiter EJ, Ooft ML, Devriese LA, Willems SM. The prognostic role of tumor infiltrating T-lymphocytes in squamous cell carcinoma of the head and neck: a systematic review and meta-analysis. Oncoimmunology. 2017; 6(11):e1356148

15. Nordfors C, Grun N, Tertipis N, Ahrlund-Richter A, Haeggblom L, Sivars L, et al. CD8+ and CD4+ tumour infiltrating lymphocytes in relation to human 
papillomavirus status and clinical outcome in tonsillar and base of tongue squamous cell carcinoma. Eur J Cancer. 2013;49(11):2522-30.

16. Wallis SP, Stafford ND, Greenman J. Clinical relevance of immune parameters in the tumor microenvironment of head and neck cancers. Head Neck. 2015;37(3):449-59.

17. Sharma S, Dominguez AL, Lustgarten J. High accumulation of T regulatory cells prevents the activation of immune responses in aged animals. J Immunol. 2006;177(12):8348-55.

18. Meucci S, Keilholz U, Tinhofer I, Ebner OA. Mutational load and mutational patterns in relation to age in head and neck cancer. Oncotarget. 2016;7(43): 69188-99.

19. Lechner A, Schlosser H, Rothschild SI, Thelen M, Reuter S, Zentis P, et al. Characterization of tumor-associated T-lymphocyte subsets and immune checkpoint molecules in head and neck squamous cell carcinoma. Oncotarget. 2017:8(27):44418-33.

20. Wu Q, Wang Q, Tang X, Xu R, Zhang L, Chen X, et al. Correlation between patients' age and cancer immunotherapy efficacy. Oncoimmunology. 2019; 8(4):e1568810

21. Kugel CH 3rd, Douglass SM, Webster MR, Kaur A, Liu Q, Yin X, et al. Age correlates with response to anti-PD1, reflecting age-related differences in Intratumoral effector and regulatory T-cell populations. Clin Cancer Res. 2018:24(21):5347-56.

22. Schuler PJ, Harasymczuk M, Schilling B, Lang S, Whiteside TL. Separation of human CD4+CD39+ T cells by magnetic beads reveals two phenotypically and functionally different subsets. J Immunol Methods. 2011;369(1-2):59-68

23. Schuler PJ, Saze Z, Hong CS, Muller L, Gillespie DG, Cheng D, et al. Human $\mathrm{CD} 4+\mathrm{CD} 39+$ regulatory $T$ cells produce adenosine upon co-expression of surface CD73 or contact with CD73+ exosomes or CD73+ cells. Clin Exp Immunol. 2014;177(2):531-43.

24. Schuler PJ, Schilling B, Harasymczuk M, Hoffmann TK, Johnson J, Lang S, et al. Phenotypic and functional characteristics of CD4+ CD39+ FOXP3+ and CD4+ CD39+ FOXP3neg T-cell subsets in cancer patients. Eur 」 Immunol. 2012;42(7):1876-85.

25. Spigel DR, McCleod M, Jotte RM, Einhorn L, Horn L, Waterhouse DM, et al. Safety, efficacy, and patient-reported health-related quality of life and symptom burden with Nivolumab in patients with advanced non-small cell lung Cancer, including patients aged 70 years or older or with poor performance status (CheckMate 153). J Thorac Oncol. 2019;14(9):1628-39.

26. Guigay J, Le Caer H, Ortholan C, Auperin A, Michel C, Mertens C. Treatment of inoperable elderly head and neck cancer patients. Curr Opin Oncol. 2019;31(3):152-9.

27. Hartmann S, Grandis JR. Treatment of head and neck cancer in the elderly. Expert Opin Pharmacother. 2016;17(14):1903-21.

28. Deaglio S, Dwyer KM, Gao W, Friedman D, Usheva A, Erat A, et al. Adenosine generation catalyzed by CD39 and CD73 expressed on regulatory $T$ cells mediates immune suppression. J Exp Med. 2007;204(6):1257-65.

29. Borsellino G, Kleinewietfeld M, Di Mitri D, Sternjak A, Diamantini A, Giometto R, et al. Expression of ectonucleotidase CD39 by Foxp3+ Treg cells: hydrolysis of extracellular ATP and immune suppression. Blood. 2007;110(4):1225-32.

30. Gourdin N, Bossennec M, Rodriguez C, Vigano S, Machon C, Jandus C, et al. Autocrine adenosine regulates tumor polyfunctional CD73+CD4+ effector T cells devoid of immune checkpoints. Cancer Res. 2018;78(13):3604-18.

31. Saavedra D, Garcia B, Lage A. T cell subpopulations in healthy elderly and lung Cancer patients: insights from Cuban studies. Front Immunol. 2017:8:146.

32. Vasson MP, Farges MC, Goncalves-Mendes N, Talvas J, Ribalta J, WinklhoferRoob B, et al. Does aging affect the immune status? A comparative analysis in 300 healthy volunteers from France, Austria and Spain. Immun Ageing. 2013;10:38.

33. Saavedra D, Garcia B, Lorenzo-Luaces P, Gonzalez A, Popa X, Fuentes KP, et al. Biomarkers related to immunosenescence: relationships with therapy and survival in lung cancer patients. Cancer Immunol Immunother. 2016;65:37-45.

34. Tao CJ, Chen YY, Jiang F, Feng XL, Jin QF, Jin T, et al. A prognostic model combining $C D 4 / C D 8$ ratio and $\mathrm{N}$ stage predicts the risk of distant metastasis for patients with nasopharyngeal carcinoma treated by intensity modulated radiotherapy. Oncotarget. 2016;7(29):46653-61.

35. Constantinidou A, Alifieris C, Trafalis DT. Targeting programmed cell death -1 (PD-1) and ligand (PD-L1): a new era in cancer active immunotherapy. Pharmacol Ther. 2018;194:84-106

36. Seiwert TY, Burtness B, Mehra R, Weiss J, Berger R, Eder JP, et al. Safety and clinical activity of pembrolizumab for treatment of recurrent or metastatic squamous cell carcinoma of the head and neck (KEYNOTE-012): an openlabel, multicentre, phase 1b trial. Lancet Oncol. 2016;17(7):956-65.
37. Ferris RL, Blumenschein G Jr, Fayette J, Guigay J, Colevas AD, Licitra L, et al. Nivolumab for recurrent squamous-cell carcinoma of the head and neck. N Engl J Med. 2016;375:1856-67.

38. Ferris RL, Blumenschein G Jr, Fayette J, Guigay J, Colevas AD, Licitra L, et al. Nivolumab vs investigator's choice in recurrent or metastatic squamous cell carcinoma of the head and neck: 2-year long-term survival update of CheckMate 141 with analyses by tumor PD-L1 expression. Oral Oncol. 2018; 81:45-51.

39. Saba NF, Blumenschein GR, Guigay J, Licitra LF, Fayette J, Harrington K, et al. Nivolumab (nivo) vs investigator's choice (IC) in patients (pts) with recurrent or metastatic (R/M) squamous cell carcinoma of the head and neck (SCCHN): analysis of CheckMate 141 by age. J Clin Oncol. 2018;36:6028.

40. Ebert LM, Schaerli P, Moser B. Chemokine-mediated control of T cell traffic in lymphoid and peripheral tissues. Mol Immunol. 2005;42:799-809.

41. Northfield J, Lucas M, Jones H, Young NT, Klenerman P. Does memory improve with age? CD85j (ILT-2/LIR-1) expression on CD8 T cells correlates with 'memory inflation' in human cytomegalovirus infection. Immunol Cell Biol. 2005;83(2):182-8.

42. Gonzalez-Arriagada WA, Lozano-Burgos C, Zuniga-Moreta R, Gonzalez-Diaz P, Coletta RD. Clinicopathological significance of chemokine receptor (CCR1, CCR3, CCR4, CCR5, CCR7 and CXCR4) expression in head and neck squamous cell carcinomas. J Oral Pathol Med. 2018;47(8):755-63.

43. Kouketsu A, Sato I, Oikawa M, Shimizu Y, Saito H, Tashiro K, et al. Regulatory T cells and M2-polarized tumour-associated macrophages are associated with the oncogenesis and progression of oral squamous cell carcinoma. Int J Oral Maxillofac Surg. 2019:48(10):1279-88.

44. Tang Y, Xu X, Guo S, Zhang C, Tang Y, Tian Y, et al. An increased abundance of tumor-infiltrating regulatory $T$ cells is correlated with the progression and prognosis of pancreatic ductal adenocarcinoma. PLoS One. 2014:9(3):e91551.

45. Shang B, Liu Y, Jiang SJ, Liu Y. Prognostic value of tumor-infiltrating FoxP3+ regulatory $T$ cells in cancers: a systematic review and meta-analysis. Sci Rep. 2015:5:15179.

46. Zumsteg ZS, Cook-Wiens G, Yoshida E, Shiao SL, Lee NY, Mita A, et al. Incidence of Oropharyngeal Cancer among elderly patients in the United States. JAMA Oncol. 2016;2(12):1617-23.

\section{Publisher's Note}

Springer Nature remains neutral with regard to jurisdictional claims in published maps and institutional affiliations.

\section{Ready to submit your research? Choose BMC and benefit from:}

- fast, convenient online submission

- thorough peer review by experienced researchers in your field

- rapid publication on acceptance

- support for research data, including large and complex data types

- gold Open Access which fosters wider collaboration and increased citations

- maximum visibility for your research: over $100 \mathrm{M}$ website views per year

At $\mathrm{BMC}$, research is always in progress.

Learn more biomedcentral.com/submission 